\title{
OCCUPATIONAL STRESS AMONG TEACHER EDUCATORS IN RELATION TO ORGANIZATIONAL CLIMATE
}

Mrs. Anju Mehta,Research Scholar,Lovely Professional University and Assistant professor,DAV College of Education for Women,Amritsar

E-mail-mehta4951@yahoo.co.in

\begin{abstract}
In the present age of science and technology, teachers are under stress due to increasing complexities of work and its divergent demands. Organizational climate is the important factor in contributing best work from teachers and students. If organizational climate is good then teachers will freely enjoy their work and can give their best to students. Congenial atmosphere of institution and good relationships can minimize their occupational stress. Teacher who is source of shaping destiny of country, in the form of making educated and well adjustment students in the class rooms, can be a best productive source only if he is getting teaching environment with no occupational stress. The present paper deal with the relationship between organizational climate and occupational stress of teachers.
\end{abstract}

\section{Indexing terms/Keywords}

Occupational Stress, Organizational climate, Teacher Educators

\section{Academic Discipline And Sub-Disciplines}

Education

\section{SUBJECT CLASSIFICATION}

\section{TYPE (METHOD/APPROACH)}

Survey /Interview

\section{Council for Innovative Research}

Peer Review Research Publishing System

Journal: International Journal of Research in Education methodology

Vol. 7, No.1

iiremeditor@gmail.com

www.ijrem.com 


\section{INTRODUCTION}

The spread of education in rapid strides is possible with the co-operation of teachers. The quality of education that goes on in an institution is directly proportional to the competency of the teacher. The teacher is the top most academic and professional person in the educational pyramid. The quality of education given to the students depends upon the quality of the teacher. He is the person who makes or mars the nation. So, the teacher occupies an important and unique place in the heart and soul of any educational institution. The modern teacher have to face the challenges of competition. In such volatile environment, they are bound to experience stress, as teachers are required to perform multiple roles. The manners in which teacher are able to cope with pressure, to a great extent reflect their level of performance. Life would be simple indeed if one's biological and psychological needs are automatically gratified but as we know there many obstacles place stress on the individual. The stress relating to occupation has become a prominent feature of modern life, exerting far reaching effects on employee's behaviour and adjustment on as well as off the job. Moreover, we are living in the era of growing complexities and pressures where human constitution and capacities are being taxed severely. Almost all occupational conditions can cause stress but occupational stress in the field of teaching has its relative importance. Only an efficient teacher can lead an occupational life without much stress, which further can improve the quality of work to a great extent. But the hard fact is that, at present, occupational stress on the teacher is increasing day by day.

Occupational stress is defined as negative environmental factors or stressors associated with a particular job. Occupational stress among teachers refers to negative effect resulting from their interaction with various aspects of occupation such as monetary and other facilities, human relations, security, recognition etc. and producing different psycho- social dynamics in the form of frustration, conflict, anxiety etc. Occupational stress among teachers in organization occurs when teachers deal with some negative factors in organization. The teachers suffer with various psychological problems like unsuitable working hours, non-coperation of students with them, low level of achievement, administration problems in organization. Occupational stress can occur when there is a discrepancy between the demands of the environment/workplace and an individual ability to carry out and complete these demands. Occupational stress can cause psychological and other types of emotional strain (eg. Dissatisfaction, fatigue, tension etc.) Occupational stress is also associated with various biological reactions that may lead ultimately to compromise health, such as cardiovascular disease or in extreme cases death.

Organizational climate has also a very important role in helping the teacher educators to perform their duties in better way. The stress problems such as isolation and descriptive behaviour on the part of students and their parents, can very conveniently be handled at the top level management amicably without putting the teachers in a stressful solution.

Halpin and Crofts (1963) the 'organizational climate' can be viewed as the organizational 'personality of a school.' Analogously "personality" is to the individual what organizational climate is to the organization.

Sharma (1971) organizational climate could be defined in terms of interaction that takes place between members of the organization when they fulfill their prescribed roles while satisfying their individual needs.

Sharma (1973) indentified six types of climates which have been defines. These types are:-

1. Open climate: - refer to an environment in which teachers obtain social needs satisfaction and enjoy a sense of accomplishment in their job.

2. Autonomous climate: -refer to an environment in which the teachers enjoy a friendly relationship and a high degree of group morale. They satisfy their social needs to great extent, moderate and enjoy a degree of job accomplishment.

3. Familiar climate: - is characterized by the friendly behavior of both the principal and the teachers. The teachers have established personal friendship among themselves and socially at least every one is a part of a large happy family.

4. Controlled climate: - refers to an environment which can be characterized as highly task oriented at the cost of social needs satisfaction of the members.

5. Paternal climate:- refers to a situation in which there is very little scope for the members to satisfy their social needs and derive job satisfaction.

6. Closed climate: - is characterized by a high degree of apathy on the organization. The organization in not moving. This climate lacks authenticity of behavior.

The stress related to occupational has become a prominent features of modern life, exerting for reaching effects on employee's behavior and adjustment on as well as off the job. Moreover, we are living in the era of growing complexities and pressure where human constitution and capacities are being taxed severely. It is well said that the stress results from imbalance between environmental demands and personal adequacies to meet those demands. However, management of stress is not possible unless the individual is aware of specific sources of stress.

\section{DELIMITATIONS}

The present study was delimited to 200 female teacher educators of Govt. and Non Govt. colleges of Education of Amritsar district only.

\section{OBJECTIVES}

1. To study and compare organizational climate of Govt. and Non-Govt. colleges of Education.

2. To study and compare occupational stress of female teacher educators of Govt. and 
Non Govt. colleges of Education.

3. To study occupational stress of teacher educators in relation to the organizational climate.

\section{HYPOTHESES}

1. There exists no significant difference between organization climate of Govt. and Non Govt. colleges of Education.

2. There exists no significant difference between the level of occupational stress of female teacher educators of Govt. and Non Govt. colleges of Education.

3. There exists no significant relationship between occupational stress of teacher educators in relation to their organizational climate.

\section{SAMPLE AND METHODOLOGY}

A sample of 200 female Teacher Educators, 100 from Govt. colleges of Education and 100 from Non Govt. colleges of Education, were selected from colleges of Education of Amritsar district. The present study was designed to see the relation of occupational stress of teacher educators with organizational climate. The descriptive survey method of investigation was employed in the present .For the purpose of arriving at meaningful results and conclusion, the statistical techniques :Mean,Standard deviation,Standard error of difference,t-test,Correlation etc. were used. Tools likeOccupational stress index by Dr. A.K. Srivastav and A.P Singh (1974c)and Organization climate index by Dr. Moti Lal Sharma(1973) were used.

\section{RESULT}

First Hypothesis states "There exists no significant difference between Organizational Climate of Govt. and Non Govt. colleges of Education" For the verification of the above mentioned hypothesis, first of all raw scores obtained from the Govt. and non Govt. colleges of Education with regards to their organizational climate were tabulated. The means standard deviations, difference between means, standard error of difference between means were calculated. Then to test whether the difference between means is significant or not t-test was applied.

\begin{tabular}{|l|l|l|l|l|l|l|}
\hline Group & $\begin{array}{l}\text { Sample } \\
(\mathrm{N})\end{array}$ & Mean $(\mathrm{X})$ & $\begin{array}{l}\text { Standard } \\
\text { Deviation }(\sigma)\end{array}$ & $\begin{array}{l}\text { Difference } \\
\text { between } \\
\text { mean (D) }\end{array}$ & $\begin{array}{l}\text { Standard error of } \\
\text { difference between } \\
\text { mean }(\sigma D)\end{array}$ & $t$ Value \\
\hline Govt. & 50 & 125.6 & 18.12 & \multirow{2}{*}{12.91} & 3.6 & 3.5 \\
\hline $\begin{array}{l}\text { Non } \\
\text { Govt. }\end{array}$ & 60 & 31.04 & 31.03 & & & \\
\hline
\end{tabular}

Table 1Showing mean (M), standard deviation $(\sigma)$ difference between means (D), standard error of difference between means $(\sigma D)$, and t-value for Organizational Climate of Govt. and Non Govt. colleges of education

While looking at the table $1 \mathrm{It}$ is clear that mean value of organizational climate Govt. and non Govt. colleges of education comes out to be 125.6 and 31.04 respectively. ' $t$ ' value is large than tabulated values at 0.01 level which shows that their exits significant difference between organizational climate of Govt. and non Govt. colleges of education. So first hypothesis is rejected.

Second Hypothesis states "There exists no significant difference between the level of occupational stress of female Teacher Educators of Govt. and Non Govt. colleges of Education". For the verification of the above mentioned hypothesis first of all raw scores obtained from the teacher educators with regards to their occupational stress were tabulated. The means standard deviations, difference between means, standard error of difference between means were calculated. Then to test whether the difference between means is significant or not test was applied.

\begin{tabular}{|c|c|c|c|c|c|c|}
\hline Group & $\begin{array}{l}\text { Sample } \\
\text { (N) }\end{array}$ & Mean $(\mathrm{X})$ & $\begin{array}{l}\text { Standard } \\
\text { Deviation }(\sigma)\end{array}$ & $\begin{array}{l}\text { Difference } \\
\text { between } \\
\text { mean (D) }\end{array}$ & $\begin{array}{l}\text { Standard } \quad \text { error of } \\
\text { difference between mean } \\
(\sigma D)\end{array}$ & $\begin{array}{l}\mathrm{t}-\text { Value } \\
\text { (Significance) }\end{array}$ \\
\hline Govt. Female & 50 & 125.45 & 18.1 & \multirow[b]{2}{*}{71.6} & \multirow[b]{2}{*}{3.5} & \multirow{2}{*}{20.5} \\
\hline $\begin{array}{ll}\text { Non } & \text { Govt. } \\
\text { Female } & \end{array}$ & 60 & 197.23 & 31.0 & & & \\
\hline
\end{tabular}

Table 2 Showing mean (M), Standard deviation $(\sigma)$ difference between means (D), standard error of difference between means $(\sigma D)$ and $t-$ value for Occupational Stress between female Teacher Educators of Govt. and Non Govt. colleges of Education. 
while looking the table 2 It is clear that mean values of female Teacher Educators of Govt. colleges and Non Govt. colleges for occupational stress comes out to be 125.45 and 197.23 respectively which shows that Teacher Educators of Non Govt. colleges have more Occupational Stress than Teachers Educators of Govt. colleges 't' value was calculated which is 20.5. ' $t$ ' value is significant at 0.1 level. So, Hypothesis (2): which states:"There exist no significant difference between level of Occupational Stress of the female Teacher Educators of Govt. colleges and Non Govt. colleges of Education is accepted.

Hypothesis: III Third Hypothesis states "There exists no significant relationship between occupational stress of Teacher Educators in relation to organizational climate".

\begin{tabular}{|l|l|l|l|}
\hline Variables & N & df & R \\
\hline $\begin{array}{l}\text { Relation between occupation stress and } \\
\text { organizational climate }\end{array}$ & 110 & 2 & -0.5 \\
\hline
\end{tabular}

Table 3

While looking at the table 3 , it is clear that correlation between occupational stress and organizational climate is -0.5 which is negative. This calculated value when compared with tabulated was found insignificant. Thus third hypothesis is rejected. Thus, there exists significant relationship between Occupational Stress of Teacher Educators in relation to Organizational Climate.

\section{FINDING AND CONCLUSION}

From the present research it was found that level of occupational stress of female teacher educators of Govt. and Non Govt. colleges of Education is almost same. Govt. and Non Govt. colleges of Education have different organizational climates and significant relationship exists between occupational stress of teacher educators in relation to Organizational Climate. On the basis of above findings and conclusion, it is suggested that workload should be according to the capacity of teachers so that they may not possess any kind of stress, incentive should be given to the teachers for extra work, teacher should be given social support to overcome negative stress, non-Govt. colleges of teacher educators are found to be less satisfied in life than Govt. colleges of teacher educators this observation suggest that Non Govt. colleges should take care of Organization Climate.

\section{REFERENCES}

[1] Bharathi, Arun T. , Reddy, N.V.2002 A Study of Sources of Job Stress among Primary School Teachers. Indian psychological abstracts and reviews, 10(1),112.

[2] Cunnighan 1975 A Survey in to the Relationship between Organizational Climate and Self-esteem of the Student .M. Ed. dissertation submitted to G.N.D.U. Amritsar.

[3] Gaur\& Dhawan 2000 A Study of Work Related Stress And Adaptation Pattern Among Women Professionals. Indian Psychological Abstracts And Reviews,.9 ( 2), 381.

[4]Kulsun, Umme 1998 Effect Of School Organizational Climate On Job Satisfaction Of Teachers. Journal Of Psycho-Lingua, 28(1), 53-56.

[5]Singh A,P. Manual Of Occupational Stress Index .Monoviagyanic Parikashan Sansthan ,Varanasi.

[6]Munn and Johnstone 1993 A Study On Teacher's Workload And Stress retrieved from www/scre.ac.uk resreport/rr/09/4.html

[7]Lakshmi and Mishra 2001 A Study Of Occupational Stress Among Working In

Emergency Services. Indian Psychological abstract and reviews, 9(1),142.

[8]Singh .R \& Jain R. 2012 Managing Job Stress-Factors And Strategies. Envision, 3, 41-48.

[9]Singh, Poonam \& Arora, Meenakshi 1998 A Study Of Relationship Between Job Stress And Social Among The Indian Nurses. Indian Psychological abstract and reviews, (6),1,26.

[10]Upadhayay, B.K \& Singh, B 2001 A Study Of Occupational Stress Among College And School Teachers. A journal of psycholingua,( 31), 49.

[11]Vashishtha, Archana \& Mishra P.C. 1998 A Study Of Social Support As A Moderate Variable Of Occupational Stress And Organizational Climate Relationship. Indian psychological abstracts and reviews, 6(1), 19. 